\title{
Physics and Beyond: Essay review of Kay Herrmann (Ed.): Grete Henry-Hermann: Philosophie-Mathematik-Quantenmechanik. Springer: Wiesbaden 2019, xv +663 pp.
}

\author{
Guido Bacciagaluppi ${ }^{1}$
}

Accepted: 23 October 2020 / Published online: 17 December 2020

(C) The Author(s) 2020

\begin{abstract}
Using the volume of her works and correspondence recently edited by K. Herrmann, I assess the significance of Grete Hermann's work.
\end{abstract}

Keywords Grete Hermann · Neo-Kantianism · Natural philosophy · Quantum mechanics

\section{Introduction}

Grete Hermann belongs in the canon of Western philosophy. At the start of her career she produced noteworthy work on abstract algebra as Emmy Noether's first doctoral student at Göttingen. From 1926 on she turned to philosophy, and arguably became the most significant philosopher of physics and one of the most original neo-Kantian philosophers of the interwar period. She continued to make notable contributions to philosophy, but dedicated the second half of her career to reconstructing the educational system in post-war Germany.

Hermann has always been known as a figure of significance in the foundations of quantum mechanics, thanks to the chapter devoted to her by Heisenberg in Physics and Beyond (Heisenberg 1971) — whose title I borrow here_-and to the ever-informed Max Jammer who discusses her work in some detail in The Philosophy of Quantum Mechanics (Jammer 1974). A renewed interest in Hermann as a philosopher of physics and neo-Kantian natural philosopher was arguably sparked by the volume by Léna Soler that included the French translation of Hermann's main essay on quantum mechanics (Hermann 1996), and by Dirk Lumma's English edition of the short version of the same (Hermann 1999).

This volume, edited by Kay Herrmann (no relation-two 'r's), collects now in the original German Hermann's entire published output on mathematics, philosophy of physics, and neo-Kantian natural philosophy, some further published and unpublished work, and more than fifty letters exchanged with Werner Heisenberg, Carl Friedrich von Weizsäcker, Paul Bernays, Max Jammer, Bartel van der Waerden and others. Brief introductory essays are included, as is a short section containing material on Heisenberg and Weizsäcker and

Guido Bacciagaluppi

g.bacciagaluppi@uu.nl

1 Descartes Centre for the History and Philosophy of the Sciences and the Humanities, Utrecht University, Utrecht, The Netherlands 
reviews of two of Hermann's works by the latter. ${ }^{1}$ The volume does not aim to cover Hermann's work in ethics and politics, ${ }^{2}$ or her contributions to education, ${ }^{3}$ but I hope to make clear that the material covered already amply substantiates my opening claim.

Section 2 of this essay review will provide a brief biographical sketch of Grete Hermann, followed in Sect. 3 by an overview of the volume. Section 4 will then sketch the development of Hermann's views, drawing on her works and correspondence as collected in Parts II and III of the volume. ${ }^{4}$

Translations of three short but representative papers from Part II are published alongside this review, with a separate introduction. It is to be hoped that the volume in its entirety will also be translated soon, making Hermann's work widely available to non-German speakers. ${ }^{5}$ If not otherwise noted, page numbers refer to the volume under review, as do numbered references to letters. ${ }^{6}$

\section{Biographical Sketch ${ }^{7}$}

Grete Hermann was born in Bremen in 1901. After being one of the few girls allowed to attend the Neues Gymnasium there, and after further obtaining a teacher's certificate, she enrolled at Göttingen in 1921 to read mathematics, physics and philosophy. She became Emmy Noether's first doctoral student there, as well as following courses by the neoKantian Leonard Nelson, whose assistant—after some hesitation—she became in January 1926, leaving mathematics for philosophy.

Nelson was a charismatic figure who had revived the philosophy of Jakob Friedrich Fries (1773-1843). ${ }^{8}$ Fries' philosophy was characterised by a critique of Kant's trascendental deduction: one cannot derive abstractly the conditions of possible experience, but only investigate them through a process of reflection on actual cognition (hence his own characterisation of his critique of reason as 'anthropological'). This leads among other things to a conception of knowledge as fallible and apt to empirical revision. In particular, as we shall see, the criteria of application of the Kantian notions are open to empirical investigation. A further innovation with respect to Kant is a widening of the conception of science beyond the disciplines that are mathematised, apodictic and systematic, thus

\footnotetext{
1 This is a far wider selection of Hermann's works than is found in the English-language counterpart to this volume (Crull and Bacciagaluppi 2017, also reviewed in this issue)—which includes instead more detailed secondary material.

2 A volume in German collecting significant works in these areas (Henry-Hermann 1985) was published shortly after Hermann's death.

3 I know of no study of Hermann's work in education, or of its links to her work in philosophy (hinted at, e.g., in Letters 45 and 46).

4 In two separate papers, I shall analyse in greater detail Hermann's contributions to neo-Kantian (natural) philosophy and her work on quantum mechanics, respectively (Bacciagaluppi in preparation $\mathrm{a}, \mathrm{b}$ ).

5 Key papers that cry out for translation are the two main papers of 1937, especially 'Über die Grundlagen physikalischer Aussagen in den älteren und den modernen Theorien' ('On the Foundations of Physical Statements in the Older and the Modern Theories', pp. 275-334), as well as 'Die Kausalität in der Physik' ('Causality in Physics', pp. 383-397) from 1948. See the Appendix for an overview of existing translations of Hermann's works.

6 All translations are either mine or from Crull and Bacciagaluppi (2017), in which case I add also the page reference to that volume. All emphases are original.

7 This subsection is mainly based on Hansen-Schaberg (2017) and on Hansen-Schaberg's essay in the volume under review (pp. 25-40).

${ }^{8}$ For this very brief characterisation of Fries, I mainly follow Paparo (2017), which is more detailed than Paparo's essay in the volume under review. See also Pulte (1999), Geldsetzer (1999) and Gregory (2006), and (with special reference to Hermann) Crull (2017), Leal (2017), Cuffaro (2020) and Bacciagaluppi (in preparation a).
} 
including sciences such as biology, chemistry and psychology. Indeed, Nelson's own circle and influence extended to scientists in many fields. Nelson placed great emphasis on the rational foundation of ethics. This led in turn to his founding of various political and educational organisations, which operated also after Nelson's early death in $1927 .{ }^{9}$ They intensified activities in the run-up to Hitler's seizure of power, in particular with the publication of the socialist daily Der Funke (The Spark). To this Hermann contributed regularly, either as herself or as 'S. H.' co-authoring with Minna Specht (also known as 'Dora' to her Nelsonian friends). She also acted with Specht as Nelson's literary executor.

After the forced cessation of open political activity, Hermann started developing her own distinct line of research in philosophy. In 1933-1935 she worked mainly on quantum mechanics, in particular spending 5 or 6 months in 1934 with Heisenberg in Leipzig. This work culminated in March 1935 with the publication of a long essay in the Abhandlungen der Fries'schen Schule, the journal founded by Nelson. Between the summer of 1934 and that of 1937 she lived and taught at the exile school of the Nelsonians in the Danish Østrupgård, ${ }^{10}$ while continuing with both non-frontline political activities and research in philosophy. Specifically, in 1936-1937 she extended her analysis of modern physics to include special and general relativity as well as Maxwellian electrodynamics, and outlined a comprehensive neo-Friesian position in natural philosophy.

Hermann's work in natural philosophy then slowed down. She spent the war in exile in England (where she had entered a marriage of convenience and started using the name Grete Henry or Grete Henry-Hermann). There, as she had since 1935, she continued to contribute under various pseudonyms to the exile paper Sozialistische Warte (Socialist Lookout) run by the Nelsonians. Her contributions were engaged pieces of political and cultural commentary and calls to plan for the reconstruction after the war-a task to which she actively contributed in the union of socialist German organisations in Great Britain (on whose executive committee she was) and in the German Educational Reconstruction Committee founded by Minna Specht. She was also a founding member of the (still active) Society for the Furtherance of Critical Philosophy, initially set up to support the exile school which had moved to Wales, but had to close when the war began and Specht and the other teachers were interned for a while as enemy aliens.

When she returned to Germany after the war, Hermann became director of the new Pädagogische Hochschule (Teacher Training College) in Bremen and was heavily engaged in the reconstruction of the educational system in Germany in various capacities, in particular as a member of the Deutscher Ausschuss für Erziehungs- und Bildungswesen

\footnotetext{
9 See, e.g., Paparo (2017) and Leal (2017). The ethical foundation of Nelson's socialism led to the expulsion of the Nelsonians from the German Social Democratic Party (SPD), since ethics is an ideological superstructure from a Marxist point of view. As a consequence, Nelson founded also a separate political party, the Internationaler Sozialistischer Kampfbund (ISK) (often translated as Militant Socialist International). Much later, the Nelsonians were instrumental in the drafting of the Godesberg Programme, which the SPD adopted in 1959 rejecting Marxism in favour of ethically based socialism-crucially Willi Eichler (who headed the ISK after Nelson's death), but as Hansen-Schaberg remarks (p. 34) also Hermann herself. Hermann's 'Ethik und Naturwissenschaft' ('Ethics and Natural Science', pp. 399-407) was also written in the context of the programmatic debate within the SPD. For Hermann's political activity, see especially Hansen-Schaberg's essay in the volume under review (pp. 25-40).

10 Nelson had set up a training institution for members of the ISK, the Walkemühle near Melsungen in Hessen. The ISK was in fact one of the most effective groups in the underground political resistance to Hitler before the war. The Walkemühle included also a children's section, which adopted radically liberal educational principles, and should perhaps be seen in the line of legendary reform schools such as Summerhill. For more on the Walkemühle school see, e.g., Hansen-Schaberg (1992).
} 
(German Committee for the Education System), an independent committee advising the States and the Federation on education. Her published work in the post-war period includes discussions of the wider relevance of modern science and natural philosophy, and work on ethics revising Nelson's 'absolutist' position. She also strived towards a parallel more comprehensive re-assessment of neo-Friesian natural philosophy. Hermann remained active in the Nelsonian and the socialist movements in Germany up to her death in Bremen in 1984.

\section{Overview of the Volume}

Part I of the volume (pp. 1-91) contains seven short essays by the editor and other contributors, as follows.

Giulia Paparo provides a lucid and informative introduction to the neo-Kantian tradition of natural philosophy initiated by Jakob Friedrich Fries and renewed by Leonard Nelson, and of how Hermann fits within it.

Kay Herrmann briefly sketches Hermann's specific analysis of quantum mechanics, and how that forms the template for her other work on physics, with particular reference to Maxwell's electrodynamics.

A superb description of Hermann's political engagement throughout her career is then given by Inge Hansen-Schaberg, with many notable details especially of Hermann's activities during her exile from Nazi Germany.

The next two essays, by Peter Ullrich and by Karl-Heinz Kiyek, usefully complement each other in describing the historical context and mathematical details of Hermann's dissertation with Emmy Noether, and are best read together.

Finally, in the last two essays, Caroline Littlejohn Herzenberg provides a wider panorama on Hermann's views on quantum mechanics, and Dieter Suter puts them in the context of other discussions of incompleteness and non-locality, especially the Bell inequalities.

These essays pave the wave for the extremely substantial Part II (pp. 93-432) which collects fifteen works by Hermann from the period 1925-1973. These are ordered chronologically, but the order also corresponds to the systematic development of Hermann's interests along the years.

(a) Mathematics is represented by her 1925 doctoral dissertation 'Die Frage der endlich vielen Schritte in der Theorie der Polynomideale' ('The Question of Finitely Many Steps in the Theory of Polynomial Ideals' (Hermann 1998)). The volume reproduces it unaltered from the Mathematische Annalen, where it was published in 1926 (pp. 97-147).

(b) Neo-Kantian reflections on epistemology follow in the period 1926-1930. We have first an unpublished talk that Hermann gave in July 1926, as part of Nelson's characteristically titled course on 'Rückschritte der Metaphysik seit Kant' ('Regresses in Metaphysics since Kant', pp. 149-172). ${ }^{11}$ It criticises the philosophy of Bernard Bolzano (1781-1848). This talk is followed by two appendices to a paper on 'Fries und die Psychologie des Sehens' ('Fries and the Psychology of Sight') published by Ludwig Ruben in the Abhandlungen (Ruben 1930). The first of the appendices by Hermann criticises 'nativist' views

\footnotetext{
11 Cf. the catalogue of Hermann's Nachlass (with many thanks to Giulia Paparo for providing me with a copy).
} 
(pp. 174-177), the longer second one is a discussion of Gestalt theory (pp. 177-183) both from a Friesian perspective.

(c) Quantum mechanics was the main focus of Hermann's philosophical work in the period 1933-1935, and is represented by five papers from the years 1933-1936. The first is a manuscript from 1933, 'Determinismus und Quantenmechanik' (pp. 185-203) ('Determinism and Quantum Mechanics' (Crull and Bacciagaluppi 2017, 223-237))—recently rediscovered in the Dirac Archive (document DRAC 3/11) - in which Hermann criticises alleged proofs of the completeness of the theory, including von Neumann's famous theorem, and thereby rebuts existing claims that quantum mechanics refutes the Kantian thesis of causality. This is the first publication of this manuscript in the original German.

There follows Hermann's main essay on the subject, 'Die naturphilosophischen Grundlagen der Quantenmechanik' (pp. 205-258) ('Natural-philosophical Foundations of Quantum Mechanics' (Crull and Bacciagaluppi 2017, 239-278)), published in the Abhandlungen in March 1935, in which, after expanding on her previous criticisms of extant arguments, Hermann develops her own argument for the completeness of quantum mechanics, as in fact already containing the causes of all measurement results. Quantum mechanics does not refute Kant on causality, rather it separates the two notions of causality and predictability, because quantum mechanics describes nature relative to particular contexts of observation. Within each context, causality still applies, but predictability is lost in the change from one context to another. I shall generally refer to this as the 'long 1935 essay'. ${ }^{12}$

This in turn is followed by the 'short 1935 essay', a substantially abridged and slightly adapted version of the long essay that was published under the same title in October 1935 in the widely distributed Die Naturwissenschaften (pp. 259-267).

Two short papers conclude this group of works: a book review for the Physikalische Zeitschrift of Popper's Logik der Forschung (the original German version of The Logic of Scientific Discovery, pp. 269-271), which includes in particular criticisms of Popper's remarks on quantum mechanics; and Hermann's comment on the paper by Schlick (1936) at the Second International Congress for the Unity of Science of June 1936 in Copenhagen, which had been devoted to 'The Problem of Causality' (pp. 273-274). (These are two of the papers translated in this issue).

(d) The analysis of modern physics within neo-Kantian natural philosophy is extended to special and general relativity and to electrodynamics in three papers from 1937.

'Die Bedeutung der modernen Physik für die Theorie der Erkenntnis' ('The Significance of Modern Physics for the Theory of Knowledge', pp. 325-377) was the first of these to be written, and extends the idea of the applicability of Kantian notions relative to a context of description to the special and general theories of relativity.

Then in 'Über die Grundlagen physikalischer Aussagen in den älteren und den modernen Theorien' ('On the Foundations of Physical Statements in the Older and the Modern Theories', pp. 275-334), Hermann develops in detail her neo-Friesian position in natural philosophy. She starts with a general discussion of perception and experience, followed by the role of Kantian notions in classical mechanics, whose criteria of application are successively revised with the development of modern physics. Specifically, electrodynamics revises the use of substance, relativity the use of space and time, and quantum mechanics that of causality.

\footnotetext{
12 The typesetting of this essay in the volume omits the distinction between sections or passages in larger and smaller type, which Hermann makes on the basis of mathematical accessibility.
} 
The short paper 'Die naturphilosophische Bedeutung des Übergangs von der klassischen zur modernen Physik' ('The Significance for Natural Philosophy of the Move from Classical to Modern Physics', pp. 379-381) briefly summarises this position. (It is the third paper also translated in this issue).

(e) Finally, wider issues are explored in four papers from 1948 to 1973. 'Die Kausalität in der Physik' ('Causality in Physics', pp. 383-397) is actually Hermann's presentation of her definitive view of quantum mechanics, and goes on in the final section to draw cautionary lessons for the debates on biology and free will. These ideas are then taken up again in more detail, specifically in the context of ethical responsibility ('Ethik und Naturwissenschaft' ('Ethics and Natural Science', pp. 399-407) and free will ('Gibt es einen freien Willen?' ('Is There Free Will?', pp. 409-416). 'Die Bedeutung der Verhaltensforschung für die Kritik der Vernunft' (pp. 417-432) (translated as 'The Significance of Behaviour Study for the Critique of Reason' (Henry 1973b)) concludes Part II of the volume, and presents Hermann's revision of Fries' and Nelson's ideas, in the context of both speculative and practical reason.

Part III is another vast treasure trove (pp. 433-620), reproducing 55 letters by or to Hermann (and two further related documents), arranged chronologically within the period 1933-1982. They thankfully include even the rendering of stenographic annotations. ${ }^{13}$

Two-thirds of these are from the 1930s (Letters 1-40) and provide exciting clues and details as to Hermann's involvement with quantum mechanics. They also indicate that Hermann was an active and respected member of both the philosophy community in Germany-in which the Nelsonians probably played a larger role than is usually acknowledged—and the physics community. Indeed, they make it look less likely that Hermann needed help to publish in Naturwissenschaften. ${ }^{14}$

The letters of the post-war period follow. The first two between Hermann and Weizsäcker touch on educational policy (Letters 41-42) ${ }^{15}$; then a group follows on Hermann's sabbatical in the summer of 1957 and winter of 1957/58, part of which was also spent with Weizsäcker in Göttingen (Letters 43-47). There are four detailed letters between Hermann and Paul Bernays on whether Fries and Nelson had misinterpreted Kant, and related to Hermann's own critique of them (Letters 48-51). Letters 52-54 between Hermann and Max Jammer are extremely revealing on Hermann's 1930s criticism of von Neumann. Two further letters from and to fellow Nelsonian Gustav Heckmann are also

\footnotetext{
13 Except for one letter to Dirac, and some from the papers of Hermann's friend and fellow Nelsonian Gustav Heckmann, all documents come from the Archiv der sozialen Demokratie in Bad Godesberg, which contains Hermann's Nachlass. Among the letters in the Heckmann papers are letters from Hermann to her mother, or rather copies (sometimes complete, sometimes mere collations of extracts) made presumably by Hermann's brother Carl, who had also studied physics at Göttingen. Of these, Letter 12 is undated but presumably written between September and December 1934, and I suspect that the end of Letter 16 may contain fragments of one or two further letters. Letter 27 from Heisenberg to Hermann (in which he asks her to send an 'offprint of her paper' to Wolfgang Pauli) is dated 6 July with no year, but it surely refers to the long essay: on 2 July 1935 Heisenberg had referred to it explicitly in writing to Pauli about his intention to formulate a reply to Einstein, Podolsky and Rosen (Pauli 1985, 407-409; translated in Bacciagaluppi and Crull 2021).

14 This point is speculative, of course. Cf. the General Discussion in Crull and Bacciagaluppi (2017, 212213).

15 Specifically, the exchange concerns the 'Tübingen Discussion' which took place at the initiative of Weizsäcker, of physicist Walter Gerlach and of educator Georg Picht (mentioned also in Letter 47), to address problems relating to high school curricula and exams. See the (presumably eyewitness) report by Wagenschein (1951).
} 
included, one relating to ethics (Letter 55) and another one to Hermann's critique of Fries and Nelson (Letter 56). Finally, Letter 57 to Van der Waerden includes a few memories of their teacher Emmy Noether.

The short Part IV (pp. 621-655) is dedicated to Werner Heisenberg and Carl Friedrich von Weizsäcker, and begins with essays by Helmut Rechenberg and Michael Drieschner, sketching themes that are central to the Naturbild (the image of the natural world) of Heisenberg and Weizsäcker, respectively.

Rechenberg passed away in November 2016 and was not able to polish the text (it is clearly the script of a talk, with the bibliography missing, and more typographical errors than in the rest of the volume). It provides an overview of how during the 1920s and 1930s Heisenberg's ideas developed into the views he expressed in the wartime manuscript 'Ordnung der Wirklichkeit' (Heisenberg 1942/1984), and of their later elaborations.

The last two items are a very favourable review by Weizsäcker in the Physikalische Zeitschrift of Hermann's long essay of 1935 (pp. 653-654), and a summary of her 'Über die Grundlagen physikalischer Aussagen...', which Weizsäcker wrote for the Zentralblatt für Mathematik und ihre Grenzgebiete (p. 655).

The Appendix (pp. 657-663) mainly consists of short biographies of the authors of the accompanying essays in Parts I and IV. The volume has no index.

\section{Hermann's Work in Physics and Beyond}

I shall now attempt to give a quick overview of Hermann's philosophical development (especially as represented in the volume), with an accent on Hermann's views on neo-Kantian natural philosophy. I shall expand on this in a separate paper (Bacciagaluppi in preparation a), but it is a fascinating subject that awaits a full treatment. ${ }^{16}$ There are also links to Hermann's work in other areas, notably ethics, as can be glimpsed from some of the later papers published in the volume (see also Leal 2017), as well as to her educational activities (cf. Letters 45 and 46).

Hermann's career began as a mathematician, indeed as Emmy Noether's first doctoral student at Göttingen, and while the topic of her dissertation of 1925 is not directly related to her later work, a little by way of introduction may be interesting to most readers.

Hermann's dissertation provides explicit bounds for algorithms to solve certain problems in abstract algebra. ${ }^{17}$ It is thus considered to be work prefiguring the theory of computer algebra that began in the 1960s, as discussed by Ullrich in Part I (pp. 49-51). Ullrich also provides the context of Hermann's dissertation, in particular the role played by Emmy Noether in the development of abstract algebra (pp. 42-44). The direct impulse for the dissertation had been a previous dissertation on the same topic by Kurt Hentzelt (who had gone missing in action in October 1914), parts of which Noether herself had reworked and published in 1922 (Hentzelt 1922). Hermann was given the task of completing and

\footnotetext{
${ }^{16}$ For existing work in this direction (with special reference to the neo-Kantian aspects of Hermann's work on quantum mechanics), see Paparo (2017), Crull (2017), Banks (2017), and Cuffaro (2020).

17 The translator of Hermann's dissertation, Michael Abramson, writes in his introduction: "The computational procedures which are presented in this paper include multivariate polynomial factorization, polynomial system solving, least common multiples, greatest common divisors, ideal quotients, divisibility of one ideal by another, fundamental ideals, norms, elementary divisor forms, associated prime ideals, primary decomposition, and isolated components" (Hermann 1998, 8).
} 
systematising the rest of the Hentzelt's results (pp. 44-46). In particular, as Hermann explains in the introduction to her dissertation, Hentzelt had only given a sketch of the calculation of the bounds (p. 97).

As further explained by Kiyek, however, Hermann's dissertation does not constitute a practical basis for computer algebra, because the algorithms and bounds she develops are far from optimal (p. 57). This is a point Hermann illustrates explicitly herself (p. 146). Also, as first noted by Veltzke (1958), one important bound given by Hermann is actually incorrect (pp. 55-56). ${ }^{18}$

The early papers from 1926-1930 are more relevant to Hermann's later work in that they contain hints of some important later themes. Most of the talk about Bolzano focuses on issues of epistemology, including notably the issue of 'unmediated knowledge', which in the post-war years Hermann will criticise in the context of Fries and Nelson. Also typically Friesian is the interest in the analysis of perception which is apparent in the appendices to Rubin. ${ }^{19}$ Indeed, for Fries the analysis of the a priori elements of our cognition is a matter of analysing our actual cognition-which is in fact a guiding principle in all of Hermann's work.

The crucial turn in Hermann's natural philosophy comes with Hermann's work on quantum mechanics, in particular her long essay of $1935 .{ }^{20}$ The paradigm example that Hermann uses is Heisenberg's $\gamma$-ray microscope, in Weizsäcker's (1931) analysis, in which one and the same collision between a photon and an electron can be used to measure the position or the momentum of the electron, depending on whether one registers the photon in the image plane or the focal plane of the microscope. In each of these contexts, one applies classical concepts (and indeed, according to Bohr, one must apply them). Such analyses reveal the causes for the measurement results, but classical concepts have only partial applicability, and which concepts are applicable to what extent depends on the chosen context of measurement.

Hermann's analysis is Friesian, in the sense that it is an analysis of how we make sense of our experience in the context of quantum mechanics. We see explicitly that the notion of causality remains indispensable but its criterion of application is revised. Hermann's analysis also fits with elements of Fries' and Nelson's understanding of transcendental idealism: not even classical physics gives us descriptions of things in themselves as substances interacting causally in space and time, because these notions apply only to the models that we construct from our finite observations, and break down in the limit as demonstrated by the antinomies. The Kantian notions play the role of 'analogies' that form the bridge between the 'symbolic', unintuitive physical description on the one hand and our observations on the other (between the formulas of physics and the data of perception). Hermann

\footnotetext{
18 Both Ullrich and Kiyek provide further extensive references.

19 The first appendix criticises the idea put forward by Hillebrand (1929) that spatial qualities are innate features of perception analogous to colours (rather than spatial cognition being an ordering principle). The second appendix, while approving of the idea that perception of a whole is not the sum of perceptions of its parts, criticises Gestalt theory for seeking a purely physiological rather than cognitive and psychological explanation of this phenomenon.

20 For further details and discussion of Hermann's analysis of quantum mechanics, see the papers in Crull and Bacciagaluppi (2017), as well as Cuffaro (2020). Here I emphasise the relevance of Hermann's work on quantum mechanics in the wider context of her work. In Bacciagaluppi (in preparation b), I discuss it from the point of view of the history and philosophy of quantum mechanics_arguing in particular that Hermann is the only author who can lay claim to a systematic and comprehensive position combining the main elements of Bohr's and Heisenberg's views into a coherent 'Copenhagen' interpretation.
} 
goes beyond Fries and Nelson, however, in arguing that quantum physics provides us with a further lesson: the physical description is itself fragmented, because it is always relative to a context of observation ('splitting of truth'). One and the same physical process (the collision between the photon and the electron in the $\gamma$-ray microscope) has more than one physical description, and the different contexts relative to which they are defined mutually limit the applicability of the Kantian a priori notions. ${ }^{21}$

The next step in Hermann's exploration of natural philosophy was the investigation of special and general relativity in 1935-1936, published as 'Die Bedeutung der modernen Physik für die Theorie der Erkenntnis' (which won the Richard Avenarius prize of the Saxon Academy of Sciences in June 1936). In it, Hermann first summarises her conclusions about quantum mechanics: the principle of causality remains indispensable, but needs to be dissociated from the idea of absolute knowledge of nature. Hermann then claims that in special and general relativity the measurements of (Euclidean) spatial lengths and temporal intervals, which themselves depend on the notion of simultaneity, play the analogous role: they remain indispensable in ordering our observations, but they lose their absolute applicability, becoming relative to global or local inertial systems, respectively. Indeed, in special relativity the application of the classical spatiotemporal notions leads us to recognise length contraction and time dilation as objectively real physical processes, but crucially relative to an inertial system. And measurements of space and time in general relativity depend on the assumption of the local validity of special relativity.

Hermann recognises that-unlike in quantum mechanics-in both special and general relativity there is an alternative absolute description in terms of a four-dimensional Minkowskian manifold. But this description is symbolic, i.e. unintuitive: the bridge between the physical formalism and observation is only provided by the intuitive notions of space and time, which thus remain indispensable.

As Hermann explains to Weizsäcker (Letter 35), in correspondence about a draft of her next major paper 'Über die Grundlagen physikalischer Aussagen...' (first presented in September 1936 at a workshop she organised in Heidelberg ${ }^{22}$ ), this is the juncture where her analysis must rely on the psychology of cognition rather than merely the structure of physical reasoning — which by itself would not privilege the global or local inertial systems over the Minkowskian manifolds.

Accordingly, 'Über die Grundlagen physikalischer Aussagen...'-which is in fact Hermann's most comprehensive treatment of natural philosophy-starts with a discussion of how we make sense of our perceptions in the context of everyday experience. Perception itself only contains some hints of temporality (extended present, direct perception of change) and spatiality (relations between different forms of sensory perception), and we construct experience out of it through the subtly interrelated use of spatial and temporal intuitions and the concepts of causality and substance. The adequacy of these intuitions and concepts is only derived from their success in solving this problem, which is an openended task. But their certainty is derived from the fact that they are constitutive of how the problem is posed in the first place.

In classical physics, there is no departure from the spatial and temporal intuitions or the concepts of causality and substance. Instead, the properties we ascribe to substances no longer correspond to sensory qualities (as they by and large do in the case

${ }^{21}$ See Crull (2017), Cuffaro (2020) and Bacciagaluppi (in preparation b) for further details.

${ }^{22}$ For some further details, see the introduction to the Hermann translations in this issue. 
of everyday experience), and we use the additional concept of interaction. As such, the mechanical world picture of classical physics conforms closely to the forms of intuition and categories deduced by Kant. As Hermann also explains in Letter 35 to Weizsäcker, her strategy is then to identify at which points the development of modern physics appears to break with these notions: electrodynamics with the concept of substance, relativity with the intuitions of space and time, and quantum mechanics with the concept of causality.

But Hermann argues that modern physics does not in fact abandon these notions. They remain indispensable and objective, instead their criteria of application turn out to depend on the relevant contexts of observation. What makes possible this renunciation of the absolute applicability of the Kantian notions is the fact that even in making sense of everyday experience they apply in subtly interrelated ways, so that in fact application of the Kantian notions in one context may turn out to constrain how they are applied in other contexts. In electrodynamics, the fields describe interactions between matter or instead vibrations in a non-material ether, depending on the experimental question asked. In relativity, descriptions of interacting objects become relative to inertial systems. In quantum mechanics, spatiotemporal and causal concepts are themselves mutually complementary, and even the formal ('symbolical') description in terms of wave functions depends on the context of observation.

'Über die Grundlagen physikalischer Aussagen...' is also a Friesian work in its analysis of how the a priori principles are applied in bridging the gap between the data and the formalism. As mentioned already in the discussion of Hermann's analysis of quantum mechanics, however, the relational aspect of her analysis is an important respect in which Hermann is herself departing from Fries and Nelson. The latter two firmly believed in the absoluteness of the applicability of the a priori principles, even though for them it was an empirical matter to discover how they were to be applied. This is a larger issue than it might seem at first sight (for both theoretical and pragmatic reasons), and was to lead to a gradual but very substantial critique of Fries and Nelson in Hermann's later work and correspondence.

There is in fact a marked peculiarity in Fries' critique of reason, which is taken over by Nelson. Kant distinguishes between the two faculties of sensibility (Sinnlichkeit) and understanding (Verstand), which are both essential to cognition. As Kant famously puts it in the Critique of Pure Reason:

Without sensibility no object would be given to us; and without understanding no object would be thought. Thoughts without content are empty; intuitions without concepts are blind. Hence it is just as necessary that we make our concepts sensible (i.e. that we add the object to them in intuition) as it is necessary that we make our intuitions understandable (i.e., that we bring them under concepts). Moreover, this capacity and this ability cannot exchange their functions. The understanding cannot intuit anything, and the senses cannot think anything. Only from their union can cognition arise (Kant 1996, pp. A51/B75-76).

Fries, however, identifies a third independent faculty of 'pure' reason (Vernunft). Thus, while for Kant the forms of intuition relate to sensibility, for Fries and for Nelson there is also 'pure intuition' which is independent of sensibility and provides 'unmediated knowledge'. The same applies for the categories of understanding. And the Friesian process of introspection, the psychological investigation that reveals the a priori elements in knowledge, is in fact making explicit this unmediated knowledge. 
Fries intends this quite literally. As Hermann quotes him in a 1971 letter to Heckmann: "Whoever may have looked just a few times through the good instruments of a Herschel or a Schröter, would possess in the unmediated dark representations of his mind the same astronomical knowledge as them. Their superiority would lie only in the cultivation of their inner introspective reflection" (Letter 56). The result, as Hermann summarises in a letter to Bernays, is a criticism he himself had made of Fries, ${ }^{23}$ that "his philosophising stands under the banner of rational faith, in fact a faith that sees humans as possessing a certainty of belief resting in the darkness of the unconscious" (Letter 51) - and in fact a faith that she distrusts.

Nelson's understanding of the process of introspection is considerably clearer. As explained, for example, by Cuffaro (2020), it is to be thought as analogous to extracting axioms and metamathematical principles from the analysis of actual mathematics-something that in fact had brought Nelson in close interaction with Hilbert. But according to Hermann, there is also a significant difference in how Nelson and Fries conceive of unmediated knowledge (even though Nelson did not perceive it as such). As she explains in Letter 56 (and in the last paper in Part II, 'Die Bedeutung der Verhaltensforschung für die Kritik der Vernunft'), Nelson believes that the sensible and rational contributions to factual knowledge consist of separate unmediated components: purely a posteriori sense impressions which are ordered through purely a priori intuitions and categories in the process of reflection. And only these constitute immediate knowledge. But in that respect Nelson's position is no more tenable than Fries'. Indeed, as is clear already from the discussion of everyday experience in 'Über die Grundlagen physikalischer Aussagen...' (or even from her 1935 review of Popper), Hermann does not believe there are any pure sensory experiences, nor does she believe that there are any incorrigible judgements.

The fundamental problem with Nelson is that, although he believes that the uncovering of the a priori principles and their criteria of application is an empirical matter, he also believes that once these are uncovered they form an absolute framework that must be adhered to by anyone who accepts the universal validity of reason. Hermann took exception to this as early as the turn of the year 1926, when Nelson asked her to comment on his 'deduction of the moral law' (Leal 2017). But it was in her reflection on quantum mechanics and her development of natural philosophy that Hermann identified the way in which this tendency in Nelson's philosophy could be set aside, namely in the recognition that what we have learned from modern physics is that the criteria of application of the a priori principles-while being objective - are also relative to the context in which they are being applied.

After the war, Hermann devoted less of her time to philosophical research, but she applied the lessons of her work on natural philosophy more widely. In a number of papers in Part II ('Die Kausalität in der Physik' from 1948, 'Ethik und Naturwissenschaft' from 1950, and 'Gibt es einen freien Willen?' from 1968) Hermann applies her insights about causality to the debates about free will, life, and ethical and political responsibility: one should not fall into the trap of thinking that modern physics has replaced causality with chance, but modern physics has shattered the mechanical world picture, and these debates pose questions defined with respect to quite different contexts.

In a number of other works and letters, Hermann confronts the limitations of Fries' and Nelson's thinking head-on. This is first evident in her 'Die Überwindung des Zufalls'

${ }^{23}$ Bernays (1953), which appeared in the same volume as Henry-Hermann (1953). 
(Henry-Hermann 1953) ('Conquering Chance' (Henry-Hermann 1991)), in which she removes the absolutist aspect from Nelson's ethics. As she writes to Heckmann in Letter 56, by the time of the Nelson centenary in 1962 she was already criticising explicitly Fries' and Nelson's position, rejecting their view of "a—static—reservoir of unmediated knowledge", in favour of "the power of reason to-dynamically—cognise, judge, trust". But at the time she was also unsure of how to think of Kant's own approach to the critique of reason (given Fries' and Nelson's critique of Kant and her own critique of Fries and Nelson).

In a fascinating exchange with Paul Bernays between May and December of 1966 (Letters 48-51), Hermann then dissects Fries' and Nelson's criticism of Kant. They accuse Kant of 'formal idealism', the doctrine that one can derive transcendental idealism purely from the aprioricity of the intuitions and the categories. ${ }^{24}$ But according to Hermann, Kant nowhere attempts such a derivation. Rather, the premise in the arguments Fries and Nelson are criticising is always and only that space and time are forms of sensible intuition and the categories are the forms of thinking about experience. What makes Fries and Nelson blind to this, Hermann suspects, is precisely the fact that in addition to sensibility and understanding they consider a separate faculty of reason. Kant does not require 'unmediated knowledge', and (as she puts it to Heckmann in Letter 56):

According to Kant the categories are not concepts in which unmediated cognisance by reason is represented conceptually, but correspond to functions (this is Kant's expression!) of the thinking about experience as determined by reason.

The exchange with Bernays contains further textual analysis of Kant, but Hermann published the essentials of her critique of Fries and Nelson in the last of the papers contained in Part II, which appeared also in English as Henry (1973b), 'Die Bedeutung der Verhaltensforschung für die Kritik der Vernunft', both in the context of speculative reason and in that of practical reason, emphasising how the study of our behaviour as agents and as social beings forms part of the anthropological critique of reason-which Fries and Nelson rightly identified as the task deriving from Kant's approach.

Hermann never published a comprehensive treatment of natural philosophy along the lines of her revised understanding of Kant and her critique of Fries and Nelson. But the depth and subtlety of her work, her uncompromising honesty, and her constant dialogue with science make her arguably the most modern and relevant representative of the neoKantian tradition in natural philosophy.

Acknowledgements I would like to thank Helmut Pulte for the invitation to contribute this review and for his and his fellow editors' encouragement and patience. I am also grateful to Mike Cuffaro for helpful correspondence during the preparation of this review, as well as to the many wonderful colleagues and friends (in particular Elise Crull) with whom and thanks to whom I have discovered the fascinating figure of Grete Hermann.

Open Access This article is licensed under a Creative Commons Attribution 4.0 International License, which permits use, sharing, adaptation, distribution and reproduction in any medium or format, as long as you give appropriate credit to the original author(s) and the source, provide a link to the Creative Commons licence, and indicate if changes were made. The images or other third party material in this article

${ }^{24}$ As explained in Cuffaro (2018, Sects. 2 and 10), Fries and Nelson see Kant as confused about whether transcendental idealism is a thesis about the world or about knowledge. They take him as arguing unsuccessfully for the ontological thesis from the aprioricity of the forms of intuition and the categories, while arguing successfully for the epistemic thesis in the doctrine of the antinomies. Thanks to Mike Cuffaro for very helpful correspondence on this matter. 
are included in the article's Creative Commons licence, unless indicated otherwise in a credit line to the material. If material is not included in the article's Creative Commons licence and your intended use is not permitted by statutory regulation or exceeds the permitted use, you will need to obtain permission directly from the copyright holder. To view a copy of this licence, visit http://creativecommons.org/licenses/by/4.0/.

\section{Appendix: Existing Translations of Works by Hermann}

The history of translations of works by Hermann is briefly as follows (see the bibliography for full details):

- 1947: Hermann's short book Politik und Ethik-including in particular her criticism of the apathy of German intellectuals under the Nazi regime-was translated as Politics and Ethics.

- 1973: 'Die Bedeutung der Verhaltensforschung für die Kritik der Vernunft' (pp. 417432) was published simultaneously in German and English in the German and English editions of Ratio (a journal originally strongly connected to the Nelsonian movement).

- 1991: Hermann's article 'Die Überwindung des Zufalls', revising her teacher Leonard Nelson's ethics, was translated by Peter Winch as 'Conquering Chance'.

- 1996: French translation of 'Die naturphilosophischen Grundlagen der Quantenmechanik' (long version, pp. 205-258). Published on the initiative of Léna Soler and with two accompanying essays by her, this translation marked the beginning of the renewed interest in Grete Hermann's work on quantum mechanics.

- 1998: Hermann's doctoral dissertation with Emmy Noether, 'Die Frage der endlich vielen Schritte in der Theorie der Polynomideale' (pp. 95-147), translated as 'The question of finitely many steps in polynomial ideal theory'.

- 1999: Dirk Lumma's translation of the short version of 'Die naturphilosophischen Grundlagen der Quantenmechanik' (pp. 259-267), with an introduction, published in the Harvard Review of Philosophy.

- 2008: Michiel Seevinck posted online a translation of Sect. 7 (on von Neumann's impossibility proof) of the long version of Hermann's essay, but this translation is currently no longer available.

- 2017: Translation of 'Determinismus und Quantenmechanik' (pp. 185-203) in Crull and Bacciagaluppi (2017).

- 2017: Translation of the long version of 'Die naturphilosophischen Grundlagen der Quantenmechanik', also in Crull and Bacciagaluppi (2017).

- 2021: New translation of the short version of 'Die naturphilosophischen Grundlagen der Quantenmechanik' (based on our translation of the long version) in Bacciagaluppi and Crull (2021).

Additionally, Hermann published in English an encyclopedia entry on Leonard Nelson (Henry-Hermann 1967), as well as in French another article on Nelson (Henry 1976).

\section{Bibliography}

This bibliography includes the works cited, the original references for works in the volume under review, and all translations of works by Hermann. 


\section{Archives}

Archiv der sozialen Demokratie, Bad Godesberg, Germany (Nachlass Grete Henry-Hermann).

Dirac Archive, University Libraries, Florida State University, Tallahassee, FL, U.S.A. (a copy of the Dirac Archive is also located in the Churchill Archives, Churchill College, Cambridge, UK).

Private collection Dieter Krohn, Bonn, Germany (Nachlass Gustav Heckmann).

\section{Works by Hermann}

Henry, G. (1973a). Die Bedeutung der Verhaltensforschung für die Kritik der Vernunft. Ratio (German edition), 15(2), 197-209. Translated as Henry (1973b).

Henry G (1973b). The Significance of Behaviour Study for the Critique of Reason. Ratio (English edition), 15(2), 206-220. Translation by 'G. S.' of Henry (1973a).

Henry, G. (1976). Leonard Nelson 1882-1927. Archives de Philosophie, 39(3), 353-365.

Henry-Hermann, G. (1948). Kausalität in der Physik. Studium Generale, 1(6), 375-383.

Henry-Hermann, G. (1950). Ethik und Naturwissenschaft. Ein Beitrag zu der von Carlo Schmid angeregten Diskussion eines sozialistischen Programms. Geist und Tat, 5(9), 383-389.

Henry-Hermann, G. (1953). Die Überwindung des Zufalls: Kritische Betrachtungen zu Leonard Nelsons Begründung der Ethik als Wissenschaft. In Specht, M., \& Eichler, W. (Eds.), Leonard Nelson zum Gedächtnis, (pp. 25-111) Frankfurt am Main/Göttingen: Verlag Öffentliches Leben. Reprinted in Henry-Hermann (1985). Translated as Henry-Hermann (1991).

Henry-Hermann, G. (1967). Nelson, Leonard. In P. Edwards (Ed.), Encyclopedia of Philosophy (Vol. 5, pp. 463-467). New York: Macmillan and The Free Press.

Henry-Hermann, G. (1968). Gibt es einen freien Willen? Alte Fragen im Licht moderner Wissenschaft. Geist und Tat, 23(1), 31-37.

Henry-Hermann, G. (1985). Die Überwindung des Zufalls. Hamburg: Meiner.

Henry-Hermann, G. (1991). Conquering Chance: Critical Reflections on Leonard Nelson's Establishment of Ethics as a Science. Philosophical Investigations, 14(1), 1-80. Translation by Peter Winch of HenryHermann (1953).

Hermann, G. (1926a). Die Frage der endlich vielen Schritte in der Theorie der Polynomideale. Mathematische Annalen, 95(1), 736-788. Translated as Hermann (1998).

Hermann, G. (1926b). Die philosophischen Lehren Bolzanos. Nachlass Grete Hermann, 1/GHAJ000002.

Hermann, G. (1930a). Die Verteidigung des Nativismus durch Hillebrand. Appendix 1 to Ruben (1930). Abhandlungen der Fries'schen Schule (Neue Folge), 5(2), 211-216.

Hermann, G. (1930b). Bemerkungen zur Gestalttheorie. Appendix 2 to Ruben (1930). Abhandlungen der Fries'schen Schule (Neue Folge), 5(2), 217-226.

Hermann, G. (1933). Determinismus und Quantenmechanik. Dirac Archives, DRAC 3/11. Translated as Hermann (2017a).

Hermann, G. (1935a). Die naturphilosophischen Grundlagen der Quantenmechanik. Abhandlungen der Fries'schen Schule (Neue Folge), 6(2), 69-152. Translated into French as Hermann (1996). Translated into English as Hermann (2017b).

Hermann, G. (1935b). Besprechung: K. Popper, Logik der Forschung. Zur Erkenntnistheorie der modernen Naturwissenschaft. $8^{\circ}$. VI u. 248 S. Berlin 1935. Julius Springer. Geh. RM 13.50. Physikalische Zeitschrift, 36(13), 481-482. Translated in this issue.

Hermann, G. (1935c). Die naturphilosophischen Grundlagen der Quantenmechanik (Auszug). Die Naturwissenschaften, 23(42), 718-721. Translated as Hermann (1999) and Hermann (2021).

Hermann, G. (1936). Zum Vortrag Schlicks. Erkenntnis, 6(5/6), 342-343. Translated in this issue.

Hermann, G. (1937a). Die Bedeutung der modernen Physik für die Theorie der Erkenntnis. In G. Hermann, E. May and Th. Vogel (Eds.), Die Bedeutung der modernen Physik für die Theorie der Erkenntnis. Drei mit dem Richard Avenarius-Preis ausgezeichnete Arbeiten (pp. 3-44). Leipzig: Hirzel.

Hermann, G. (1937b). Über die Grundlagen physikalischer Aussagen in den älteren und den modernen Theorien. Abhandlungen der Fries'schen Schule (Neue Folge), 6(3/4), 309-398.

Hermann, G. (1937c). Die naturphilosophische Bedeutung des Übergangs von der klassischen zur modernen Physik. In R. Bayer (Ed.), Travaux du IX Congrès International de Philosophie-Congrès Descartes. Vol. VII, Causalité et Déterminisme. Actualités Scientifiques et Industrielles, n. 536 (pp. 99-101). Paris: Hermann et $\mathrm{C}^{\mathrm{ie}}$. Translated in this issue.

Hermann, G. (1945). Politik und Ethik. London: Renaissance Publishing Co. Translated as Hermann (1947). 
Hermann, G. (1947). Politics and Ethics. Bombay: International Publishing Company. Translation of Hermann (1945).

Hermann, G. (1996). Les fondements philosophiques de la mécanique quantique. Edited with introduction and postface by L. Soler. Paris: Vrin. Translation by A. Schnell of Hermann (1935a).

Hermann, G. (1998). The Question of Finitely Many Steps in the Theory of Polynomial Ideals. Communications in Computer Algebra, 32(3), 8-30. Translation with introduction by M. Abramson of Hermann (1926a).

Hermann, G. (1999). The Foundations of Quantum Mechanics in the Philosophy of Nature. The Harvard Review of Philosophy, 7(1), 35-44. Translation with introduction by D. Lumma of Hermann (1935c).

Hermann, G. (2017a). Determinism and Quantum Mechanics. In Crull, E. \& Bacciagaluppi, G. (Eds.), Grete Hermann-Between Physics and Philosophy. Studies in History and Philosophy of Science (Vol. 42), (pp. 223-237). Dordrecht: Springer.

Hermann (2017b). The Natural-philosophical Foundations of Quantum Mechanics. In Crull, E. \& Bacciagaluppi, G. (Eds.), Grete Hermann-Between Physics and Philosophy. Studies in History and Philosophy of Science (Vol. 42), (pp. 239-278). Dordrecht: Springer.

Hermann, G. (2021). The Natural-philosophical Foundations of Quantum Mechanics (Excerpt). In Bacciagaluppi and Crull (2021). Translation by G. Bacciagaluppi and E. Crull of Hermann (1935c).

\section{Works by Others}

Bacciagaluppi, G. (in preparation a). Kantianism with a Human Face: Grete Hermann's Critical Philosophy', in preparation.

Bacciagaluppi, G. (in preparation b). Better than Bohr: Grete Hermann and the Copenhagen Interpretation', in preparation.

Bacciagaluppi, G., \& Crull, E. (2021). The Einstein Paradox: The Debate on Nonlocality and Incompleteness in 1935. Cambridge: CUP (Forthcoming).

Banks, E. C. (2017). Grete Hermann as neo-Kantian Philosopher of Space and Time Representation. Journal for the History of Analytical Philosophy, 6, 245-263.

Bernays, P. (1953). Über die Fries'sche Annahme einer Wiederbeobachtung der unmittelbaren Erkenntnis. In Specht, M., \& Eichler, W. (Eds.), Leonard Nelson zum Gedächtnis, (pp. 113-131) Frankfurt am Main/Göttingen: Verlag Öffentliches Leben.

Crull, E. (2017). Hermann and the Relative Context of Observation. In Crull, E. \& Bacciagaluppi, G (Eds.), Grete Hermann-Between Physics and Philosophy. Studies in History and Philosophy of Science (Vol. 42), (pp. 149-169). Dordrecht: Springer.

Crull, E., and Bacciagaluppi, G. (Eds.) (2017). Grete Hermann-Between Physics and Philosophy. Studies in History and Philosophy of Science, Vol. 42. Dordrecht: Springer.

Cuffaro, M. E. (2018). Kantian and neo-Kantian First Principles for Physical and Metaphysical Cognition. PhilSci Archive preprint, http://philsci-archive.pitt.edu/15350/.

Cuffaro, M. E. (2020). Grete Hermann, Quantum Mechanics, and the Evolution of Kantian Philosophy. In J. Peijnenburg \& A. A. Verhaegh (Eds.), Women in the history of analytic philosophy. Dordrecht: Springer (Forthcoming).

Geldsetzer, L. (1999). Jakob Friedrich Fries' Stellung in der Philosophiegeschichte. In Hogrebe and Herrmann (1999) (pp. 13-56).

Gregory, F. (2006). Extending Kant: The Origins and Nature of Jakob Friedrich Fries's Philosophy of Science. In M. Friedman \& A. Nordmann (Eds.), The Kantian Legacy in Nineteenth-century Science (pp. 101-121). Cambridge, MA: The MIT Press.

Hansen-Schaberg, I. (1992). Minna Specht-Eine Sozialistin in der Landerziehungsheimbewegung (1918 bis 1951). Untersuchung zur pädagogischen Biographie einer Reformpädagogin. Frankfurt am Main: Lang.

Hansen-Schaberg, I. (2017). A Biographical Sketch of Prof. Dr Grete Henry-Hermann (1901-1984). In Crull, E. \& Bacciagaluppi, G. (Eds.), Grete Hermann-Between Physics and Philosophy. Studies in History and Philosophy of Science (Vol. 42), (pp. 3-16). Dordrecht: Springer.

Heisenberg, W. (1971). Physics and Beyond: Encounters and Conversations. New York: Harper and Row.

Heisenberg, W. (1984). Ordnung der Wirklichkeit. In Gesammelte Werke, Series C, Volume I: Physik und Erkenntnis 1927-1955. Edited by W. Blum, H.-P. Dürr and H. Rechenberg (pp. 217-306). München: Piper.

Hentzelt, H. (1922). Zur Theorie der Polynomideale und Resultanten. Edited by Emmy Noether. Mathematische Annalen, 88, 53-79. 
Hillebrand, F. (1929). Lehre von den Gesichtsempfindungen. Edited by Franziska Hillebrand. Wien: Springer.

Hogrebe, W., \& Herrmann, K. (Eds.). (1999). Jakob Friedrich Fries: Philosoph, Naturwissenschaftler und Mathematiker. Frankfurt am Main: Lang.

Jammer, M. (1974). The Philosophy of Quantum Mechanics: The Interpretations of Quantum Mechanics in Historical Perspective. Hoboken, NJ: Wiley.

Kant, I. (1996). Critique of Pure Reason. Translated by W. S. Pluhar. Indianapolis: Hackett Publishing.

Leal, F. (2017). Grete Hermann as a Philosopher. In Crull, E. \& Bacciagaluppi, G. (Eds.), Grete HermannBetween Physics and Philosophy. Studies in History and Philosophy of Science (Vol. 42), (pp. 17-34). Dordrecht: Springer.

Paparo, G. (2017). Understanding Hermann's Philosopy of Nature. In Crull, E. \& Bacciagaluppi, G. (Eds.), Grete Hermann-Between Physics and Philosophy. Studies in History and Philosophy of Science, (Vol. 42), (pp. 35-51). Dordrecht: Springer.

Pauli, W. (1985). Scientific Correspondence with Bohr, Einstein, Heisenberg a.o., Vol. II, 1930-1939. Edited by K. von Meyenn. Berlin: Springer.

Pulte, H. (1999). “...sondern Empirismus und Speculation sich verbinden sollen.” Historiographische Überlegungen zur bisherigen Rezeption des wissenschaftstheoretischen und naturphilosophischen Werkes von J. F. Fries und einige Gründe für dessen Neubewertung. In Hogrebe and Herrmann (1999) (pp. 57-94).

Ruben, L. (1930). Fries' Bedeutung für die psychologische Theorie des Sehens. Abhandlungen der Fries'schen Schule (Neue Folge), 5(2), 115-210.

Schlick, M. (1936). Quantentheorie und Erkennbarkeit der Natur. Erkenntnis, 6(5/6), 317-326.

Specht, M., \& Eichler, W. (Eds.). (1953). Leonard Nelson zum Gedächtnis. Frankfurt am Main/Göttingen: Verlag Öffentliches Leben.

Veltzke, C. (1958). Berechnungsprobleme bei Polynomidealen. Diploma thesis. Faculty of Mathematics and Physics, Humboldt University, Berlin.

Wagenschein, M. (1951). Das Tübinger Gespräch. Die Pädagogische Provinz, 5(12), 623-628.

von Weizsäcker, C. F. (1931). Ortsbestimmung eines Elektrons durch ein Mikroskop. Zeitschrift für Physik, $70(1 / 2), 114-130$.

von Weizsäcker, C. F. (1936). Besprechung: Grete Hermann. Die naturphilosophischen Grundlagen der Quantenmechanik. Physikalische Zeitschrift, 37, 527-528.

Weizsäcker, C. F. von (1937). Kurzreferat: Hermann, Grete. Über die Grundlagen physikalischer Aussagen in den älteren und den modernen Theorien. Abh. Fries'sche Schule, N. s. 6, 309-398. Zentralblatt für Mathematik und ihre Grenzgebiete, 16, 339.

Publisher's Note Springer Nature remains neutral with regard to jurisdictional claims in published maps and institutional affiliations. 